\title{
Digestibility and nutrient retention of a wheat bran- containing diet containing two vegetable oil sources applied to laying hens with emphasis on prefeeding period
}

\author{
Verdaulichkeit und Nährstoffretention von Weizenkleie- \\ haltigem Legehennenfutter mit zwei verschiedenen pflanzlichen \\ Ölen - unter Berücksichtigung der Adaptationszeit
}

\author{
Elisa Wanzenböck ${ }^{1 *}$, Matthias Schreiner ${ }^{1}$, Ulrike Zitz ${ }^{1}$, Sophie Figl ${ }^{2}$, Wolfgang Kneifel ${ }^{1}$, Karl Schedle ${ }^{2}$ \\ ${ }^{1}$ Institute of Food Science, University of Natural Resources and Life Sciences Vienna (BOKU), Muthgasse 18, 1190 Vienna, Austria \\ ${ }^{2}$ Institute of Animal Nutrition, Livestock Products, and Nutrition Physiology, University of Natural Resources and Life Sciences Vienna \\ (BOKU), Muthgasse 18, 1190 Vienna, Austria \\ * Corresponding Author: elisa.wanzenboeck@boku.ac.at
}

Received: 24 September 2018, received in revised form: 26 November 2018, accepted: 4 December 2018

\begin{abstract}
Summary
A feeding trial with laying hens was conducted to study the effect of rising levels of dietary wheat bran (WB) and two vegetable oils on digestibility and retention. In addition, two different adaption times were evaluated. The following treatments were applied: no WB/29 g/kg rapeseed oil, no WB/29 g/kg sunflower oil, $75 \mathrm{~g} / \mathrm{kg} \mathrm{WB} / 45 \mathrm{~g} / \mathrm{kg}$ rapeseed oil, $75 \mathrm{~g} / \mathrm{kg} \mathrm{WB} / 45 \mathrm{~g} / \mathrm{kg}$ sunflower oil, $150 \mathrm{~g} / \mathrm{kg} \mathrm{WB} / 62 \mathrm{~g} / \mathrm{kg}$ rapeseed oil, and $150 \mathrm{~g} / \mathrm{kg} \mathrm{WB} / 62 \mathrm{~g} / \mathrm{kg}$ sunflower oil. Samples of excrements were examined for dry matter, crude protein, ether extracts, starch, neutral detergent fiber, short-chain fatty acids, and elemental analyses. The effect of the adaption time showed a significantly negative effect on the digestibility of NDF and the retention of phosphorus when a longer prefeeding period was applied. Furthermore, the results demonstrate that regardless of high dietary fiber content, laying hens are capable of tolerating higher dietary fiber levels compared to the fiber level of corn soybean meal diets. Precondition is a balanced nutrient content between diets. Therefore, wheat bran supplementation can be regarded as an interesting option for a sustainable utilization of by-products to produce food of animal origin.
\end{abstract}

Keywords: Wheat bran, digestibility, laying hens, vegetable oils, adaptation

\section{Zusammenfassung}

Ziel dieser Fütterungsstudie mit Legehennen war es, den Einfluss von Weizenkleie (WB) und zwei unterschiedlichen pflanzlichen Ölen im Futter auf die Verdaulichkeit und Retention der Nährstoffe zu untersuchen. Zusätzlich wurden zwei Adaptationszeiten (drei Tage und 15 Tage) berücksichtigt. Zu diesem Zweck wurden 24 Legehennen sechs Versuchsgruppen zugeordnet: keine WB/29 g/kg Rapsöl, keine WB/29 g/kg Sonnenblumenöl, 75 g/kg WB/45 g/kg Rapsöl, 75 g/kg WB/45 g/kg Sonnenblumenöl, $150 \mathrm{~g} / \mathrm{kg} \mathrm{WB} / 62 \mathrm{~g} / \mathrm{kg}$ Rapsöl und $150 \mathrm{~g} / \mathrm{kg} \mathrm{WB} / 62 \mathrm{~g} / \mathrm{kg}$ Sonnenblumenöl. In den Exkrementen wurden Trockenmasse, Rohprotein, Rohfett, Stärke, in neutraler Detergenzienlösung lösliche Faser (NDF), kurzkettige Fettsäuren und Mineralstoffe untersucht, um die Verdaulichkeit zu beurteilen. Der Einfluss der Adaptationszeit auf die Verdaulichkeit und Retention der Nährstoffe war kaum nachweisbar, außer bei den Parametern NDF und Phosphor verursachte eine längere Adaptionszeit eine signifikant schlechtere Verdaulichkeit/Retention. Überdies zeigen die Ergebnisse, dass trotz eines Rückganges von Verdaulichkeit und Retention durch den Einsatz von Weizenkleie, Legehennen durchaus auch höhere Fasergehalte im Vergleich zu Mais-Sojaextraktionsschrot basierten Rationen tolerieren. Voraussetzung ist ein ausbalancierter Nährstoffgehalt zwischen den Futterrationen. Der Einsatz von Weizenkleie im Legehennenfutter bietet eine zukunftsorientierte Möglichkeit, um Nebenprodukte nachhaltig in Lebensmittel tierischer Herkunft zu transformieren.

Schlagworte: Weizenkleie, Verdaulichkeit, Legehennen, Pflanzenöl, Adaptation 


\section{Introduction}

Owing to a rising global demand for animal-based protein sources as well as because of the beneficial effects on gut physiology, the inclusion of feed stuffs rich in dietary fiber gained considerable interest. Among these sources, wheat bran (WB) can be considered as such a fiber source comprising high amounts of dietary fiber and also protein, starch, minerals, and some bioactive compounds (Wanzenböck et al., 2017). As a side product of the milling industry, WB accumulates globally up to 150 million tons per year. As there is some evidence for a growing competition between humans and animals for crops as nutrients, the use of agricultural by-products such as WB has stimulated research with emphasis on biorefinery and sustainability (Apprich et al., 2014; Kraler et al., 2015). Taking into account that compared to other monogastric animals, the gastrointestinal enzyme system of laying hens is not very well developed (Jørgensen et al., 1996), dietary fiber originating from WB may stimulate the secretion of bile acids and support the natural function of the gizzard as well as the integrity of the mucosa in the small intestine (Jaroni et al., 1999). In the gut, dietary fiber is usually degraded to short-chain fatty acids (SCFAs) such as butyrate, propionate, and acetate. Through the supplementation with WB containing dietary fiber, the production of SCFAs can be improved. These SCFAs provide energy for the colonocytes, modulate the immune system, further possess some anti-inflammatory potential, strenghten the intestinal barrier, and modulate oxidative stress reactions (Hamer et al., 2008; Nyangale et al., 2012). Unfortunately, higher levels of WB in the diet may account for some lack of energy. For this purpose, sunflower oil and rapeseed oil were supplemented as additional energy source. As these oils show different fatty acid profiles, the digestibility may be divergent (Baiāo et al., 2005; Wanzenböck et al., 2018). Following the abovementioned approach, the present study deals with an investigation of a WB-containing diet in laying hens' feeding. Usually, such in vivo experiments studying the apparent digestibility and retention of feed in laying hens require an adaption period, followed by a corresponding sample collection period. In the course of the adaption period, feed residues from the previous feeding regimen are gradually eliminated. To obtain steady-state conditions, an appropriate adaption time is warranted to ensure some representative collection of the excrements (GfE 2005; Farenzena et al., 2017). In addition, to ensure reliability of measurements regarding the digestibility and retention of nutrients in laying hens, their accommodation in metabolism cages is required. These conditions, however, not only imply a restricted social contact but also a lack of free moving space for the birds. Hitherto no studies were undertaken to find out the minimum adaption time necessary for performing digestibility trials with laying hens. To promote the precision of the measurements, longer adaption times are usually requested. However, such a strategy, on the one hand, impairs animal welfare and, on the other hand, raises the costs for such a feeding experiment. In order to ensure animal welfare and also to keep the animal stressing period as short as possible, we, therefore, should aim at the shortest possible adaption periods. Hence, the present study was carried out to investigate the apparent digestibility and retention of diets supplemented with 0 , 75 , and $150 \mathrm{~g} / \mathrm{kg}$ of WB and rapeseed oil or sunflower oil and further to take into account the relevant duration of the prefeeding period based on two selected periods.

\section{Materials and Methods}

\subsection{Animals, housing, and diets}

The feeding experiment was approved by the ethics commission of the Austrian Ministry of Science and Research (BMWF-66.016/0010-WF/V/3b/2016) and by the Austrian Agency for Health. In total, 24 Lohman Brown-Classic laying hens purchased from a commercial breeder (35 weeks old) with an initial body weight of 2,000 $\pm 269 \mathrm{~g}$ were subjected to this feeding trial. According to their body mass, the individuals were weighed, leg-tagged, and randomly distributed to six feeding regimens. As each hen was accommodated in one cage, controlled feeding and total excrement collecting was ensured. The hens were fed equal amounts of feed twice daily (8:00 AM and 5:00 PM), the feed intake was limited to $110 \mathrm{~g} /$ day and water was provided ad libitum. The metabolism cages $(\mathrm{l}=50 \mathrm{~cm} \times \mathrm{b}=50 \mathrm{~cm} \times$ $\mathrm{h}=76 \mathrm{~cm}$ ) were equipped with a drinker, a wooden perch, and an attached laying nest $(1=42 \mathrm{~cm} \times \mathrm{b}=30 \mathrm{~cm} \times \mathrm{h}$ $=40 \mathrm{~cm}$ ). Moreover, laying hens were exposed to light for $16 \mathrm{~h} /$ day and the individual health status of all laying hens was recorded daily. Before the experimental period, the diet applied was a commonly used feed mixture for laying hens consists of corn, wheat, soybeans, rapeseed meal, sunflower extraction meal, WB, and soy oil. Treatments were arranged 
as a $3 \times 2$ factorial design, with three levels of WB $(0,75$, and $150 \mathrm{~g} / \mathrm{kg}$ ) and rapeseed oil or sunflower oil as vegetable oil sources $(29,45$, and $62 \mathrm{~g} / \mathrm{kg})$. To meet or exceed the nutrition recommendations for laying hens of the manufacturer (Lohmann, Cuxhaven, Germany), the diets were calculated to reach the recommended crude protein $(170 \mathrm{~g} / \mathrm{kg})$, digestible amino acids content, and metabolizable energy (11.4 $\mathrm{AME}_{\mathrm{N}}$ ). A detailed description of the diet composition applied was published previously (Wanzenböck et al., 2018). Briefly, the WB supplementations were substituted at 75 and $150 \mathrm{~g} / \mathrm{kg}$ to a basal diet comprising mainly corn and soybean meal. Rising amounts of vegetable oil were required in diets, including increasing contents of $\mathrm{WB}$, to keep the ME level constant. Coefficients of total tract apparent digestibility (CTTAD) and total tract apparent retention (CTTAR) were calculated according to the formula (nutrient intake - nutrient excretion)/nutrient intake.

\subsection{Sample collection and procedures}

Hens were weighed at the beginning and at the end of the study. The experiment lasted for 21 days. Excreta were quantitatively collected for each hen from day 3 to day 9 and from day 16 to day 21 , respectively, and pooled to one sample per period and laying hen. For further analyses, the homogenized samples were dried in an oven at $55^{\circ} \mathrm{C}$ during 5 days or immediately stored at $-18^{\circ} \mathrm{C}$ for protein and SCFA analysis. Representative samples of all tested diets and dried excrements were ground in a Retsch ultra-centrifugal mill of type ZM1 (Haan, Germany) with a 1-mm sieve. Samples of feed and excrements were analyzed in duplicates for dry matter, ash, nitrogen $(\mathrm{N})$, and ether extract (EE) according to the official methods of Verband deutscher landwirtschaftlicher Untersuchungs- und Forschungsanstalten (Naumann et al., 2012). In addition, samples of excrements were examined for starch and neutral detergent fiber (NDF) according to Naumann et al. (2012). Phytic acid content was measured according to Makkar et al. (2007). Calcium, sodium, and zinc were analyzed using an atomic absorption spectrophotometry (AAnalyst 200, Perkin Elmer, Brunn am Gebirge, Austria). After wet ashing in a microwave oven (MLS-ETHOS plus Terminal 320, Leutkirch, Germany), the phosphorus content was determined according to the vanadomolybdate method based on the absorption measurement at $436 \mathrm{~nm}$ (U5100-Spectrophotometer-Hitatchi, Metrohm, Wien, Austria). The metabolizable energy (ME) content in the diets was calculated using the formula for compound feed of the Gesellschaft für Ernährungsphysiologie (1999).

SCFAs concentrations in digesta were determined using a gas chromatographic system (Agilent Technologies 7890 A, Agilent Technologies, Santa Clara, USA) equipped with a Nukol $^{\mathrm{TM}}$ Silica Capillary column $[15 \mathrm{~m} \times 0.53 \mathrm{~mm}, 0.5 \mu \mathrm{m}$ (Supelco, Bellefonte, USA)] by applying the method of Zhao et al. (2006).

\subsection{Statistical analysis}

Statistical analysis was performed by applying a two-way analysis of variance using the mixed procedure of SAS Enterprise Guide 7.1. Data were calculated according to the following model: $x i j k=\mu+\alpha i+\beta i+\gamma i(\alpha \beta \gamma) i j+A k+$ eijk, where $\mathrm{x}$ is the dependent variable, $\mu$ is the overall mean, $\alpha$ is the effect of WB $(0,75$, and $150 \mathrm{~g} / \mathrm{kg}), \beta$ is the effect of oil (rapeseed oil or sunflower oil), $\gamma$ is the effect of period (days 4-9 and days 16-21), Ak is the random effect of animals $(\mathrm{k}=1,2, \ldots, 24)$, and eijk is the residual experimental error. Multiple comparisons of the means were evaluated using the Tukey-Kramer test. Significant differences in the means are displayed with different superscripts, and treatment means were presented as least squares means (Tables 1-3).

\section{Results}

\subsection{Total tract apparent digestibility and retention of nutrients, minerals, and energy}

Tables 1 and 2 display the resulting CTTAD and CTTAR of nutrients and minerals of the diets containing the different WB and oil supplementations as well as the effect of the prefeeding period. No differences between different levels of WB were evident concerning the CTTAD of total $\mathrm{EE}$ and NDF and the retention of ash, calcium, sodium, and phosphorus. However, 15\% WB in the diet influenced the CTTAD of dry matter $(-12.4 \%)$, and starch $(-1.5 \%)$, as well as the CTTAR of $\mathrm{N}(-22.8)$ and zinc $(-123.8 \%)$. Furthermore, oil supplementation had no influence on CTTAD and CTTAR. The prefeeding period showed an effect on CTTAD of NDF (-21.2\%) and on CTTAR of phosphorus $(-62.2 \%)$ with increasing prefeeding period. Furthermore, a significant interaction of $\mathrm{WB} \times$ period was observed for sodium, whereas the interactions for all other nutrients were not significant. 
Table 1. Coefficients of total tract apparent digestibility of dry matter, starch, ether extract, and neutral detergent fiber from hens fed with different wheat bran (WB) levels and oil supplementations. Data represent LS means and standard error of means (SEM), as well as significance levels of the influence of WB, period, and oil supplementation, including their interactions (WB $\times$ Oil; WB $\times$ Period; Oil $\times$ Period; WB $\times$ Oil $\times$ Period) .

Tabelle 1. Koeffizienten der Gesamttrakt-Verdaulichkeit von Trockenmasse, Stärke, Fett und Neutral-detergent Fiber von Legehennen, die mit ansteigenden Gehalten von Weizenkleie sowie verschiedenen pflanzlichen Ölen gefüttert wurden. Die Daten zeigen die LS-Mittelwerte, den Standardfehler der Mittelwerte und das Signifikanzlevel von Weizenkleie, Öl, Periode sowie deren Interaktionen.

\begin{tabular}{|c|c|c|c|c|}
\hline \multirow[b]{4}{*}{$0 \mathrm{~g} / \mathrm{kg}$} & \multicolumn{4}{|c|}{ Coefficients of total tract apparent digestibility } \\
\hline & Dry matter & Crude starch & Ether extract & Neutral detergent fiber \\
\hline & \multicolumn{4}{|c|}{ Wheat bran } \\
\hline & $75.83^{\mathrm{a}}$ & $99.11^{\mathrm{a}}$ & 84.00 & 36.20 \\
\hline $75 \mathrm{~g} / \mathrm{kg}$ & $71.76^{\mathrm{b}}$ & $98.47^{\mathrm{a}}$ & 84.45 & 38.79 \\
\hline \multirow[t]{2}{*}{$150 \mathrm{~g} / \mathrm{kg}$} & $67.47^{c}$ & $97.66^{\mathrm{b}}$ & 85.04 & 38.24 \\
\hline & \multicolumn{4}{|c|}{ Vegetable oil } \\
\hline Rapeseed oil & 71.62 & 98.33 & 84.23 & 37.287 \\
\hline \multirow[t]{2}{*}{ Sunflower oil } & 71.75 & 98.50 & 84.77 & 38.197 \\
\hline & \multicolumn{4}{|c|}{ Period } \\
\hline Days 4-9 & 71.99 & 98.40 & 84.25 & $41.36^{\mathrm{a}}$ \\
\hline \multirow[t]{2}{*}{ Days $16-21$} & 71.38 & 98.43 & 84.74 & $34.13^{\mathrm{b}}$ \\
\hline & \multicolumn{4}{|c|}{ p-Values } \\
\hline WB & *** & $* * *$ & n.s. & n.s. \\
\hline Oil & n.s. & n.s. & n.s. & n.s. \\
\hline Period & n.s. & n.s. & n.s. & $* * *$ \\
\hline WB $\times$ Oil & n.s. & n.s. & $* *$ & n.s. \\
\hline $\mathrm{WB} \times$ Period & n.s. & n.s. & n.s. & n.s. \\
\hline Oil $\times$ Period & n.s. & n.s. & n.s. & n.s. \\
\hline Oil $\times$ Period $\times$ WB & n.s. & n.s. & n.s. & n.s. \\
\hline SEM & 0.645 & 0.118 & 0.365 & 1.137 \\
\hline
\end{tabular}

WB: wheat bran; SEM: standard error of means; n.s. $=\mathrm{p}>0.1 ;^{*}=\mathrm{p}<0.1 ;{ }^{* *}=\mathrm{p}<0.05 ;{ }^{* * *}=\mathrm{p}<0.001$

\subsection{Short-chain fatty acids}

Owing to the fact that the influence of the prefeeding period on the CTTAD and CTTAR of nutrients was hardly pronounced, the SCFA concentrations of period 1 have not been considered. Thus, Table 3 only lists the SCFA levels and corresponding percentage of distribution measured during period 2 . The results indicate that no significant differences were observed in the absolute amounts of iso-butyric acid, iso-valeric acid, and branched-chain fatty acids (BCFAs) and the total amount of SCFA among the different feeding regimens. However, WB supplementation increased the concentrations of acetic acid, propionic acid, butyric acid, valeric acid, and caproic acid. At a sup- plementation of $150 \mathrm{~g} / \mathrm{kg}$ WB to the laying hen's diet, the levels of acetic acid were decreased by $5.0 \%$ but those of butyric acid and propionic acid were increased by $47.0 \%$ and $47.1 \%$, respectively. The application of the two different vegetable oils had no significant effects on the SCFA profiles of the excrements.

\section{Discussion}

\subsection{Chemical composition of feed}

Before the experimental trial, the diet applied was a commonly used diet for laying hens including corn, wheat, 
Table 2. Coefficients of total tract apparent retention of crude protein, crude ash, zinc, calcium, sodium, and phosphorus from hens fed with different wheat bran (WB) levels and oil supplementations. Data represent LS means and standard error of means (SEM), as well as significance levels of the influence of WB, period, and oil supplementation, including their interactions $(\mathrm{WB} \times \mathrm{O}$ il; $\mathrm{WB} \times$ Period; Oil $\times$ period; WB $\times$ Oil $\times$ Period). Tabelle 2. Koeffizienten der Gesamttraktretention von Rohprotein, Rohasche, Zink, Kalzium, Natrium und Phosphor von Legehennen, die mit ansteigenden Gehalten von Weizenkleie sowie verschiedenen pflanzlichen Ölen gefüttert wurden. Die Daten zeigen die LS-Mittelwerte, den Standardfehler der Mittelwerte und das Signifikanzlevel von Weizenkleie, Öl, Periode sowie deren Interaktionen.

\begin{tabular}{|c|c|c|c|c|c|c|}
\hline \multirow[b]{4}{*}{$0 \mathrm{~g} / \mathrm{kg}$} & \multicolumn{6}{|c|}{ Coefficients of total tract apparent retention } \\
\hline & Crude protein & Crude ash & Zinc & Calcium & Sodium & Phosphorus \\
\hline & \multicolumn{6}{|c|}{ Wheat bran } \\
\hline & $45.04^{\mathrm{a}}$ & 54.31 & $21.19^{a}$ & 61.03 & 61.25 & 31.15 \\
\hline $75 \mathrm{~g} / \mathrm{kg}$ & $43.31^{\mathrm{a}}$ & 50.96 & $17.00^{\mathrm{a}}$ & 63.64 & 61.46 & 28.24 \\
\hline \multirow[t]{2}{*}{$150 \mathrm{~g} / \mathrm{kg}$} & $36.68^{\mathrm{b}}$ & 45.40 & $9.47^{b}$ & 57.91 & 60.29 & 26.15 \\
\hline & \multicolumn{6}{|c|}{ Vegetable Oil } \\
\hline Rapeseed oil & 41.94 & 51.43 & 14.44 & 62.69 & 61.22 & 27.97 \\
\hline \multirow[t]{2}{*}{ Sunflower oil } & 41.42 & 49.02 & 17.34 & 59.03 & 60.77 & 29.06 \\
\hline & \multicolumn{6}{|c|}{ Period } \\
\hline Days 4-9 & 42.02 & 50.77 & 17.73 & 62.21 & 69.44 & $35.28^{\mathrm{a}}$ \\
\hline \multirow[t]{2}{*}{ Days 16-21 } & 41.34 & 49.68 & 14.05 & 59.50 & 52.55 & $21.75^{\mathrm{b}}$ \\
\hline & \multicolumn{6}{|c|}{ p-Value } \\
\hline WB & $* *$ & n.s. & $* * *$ & n.s. & n.s. & n.s. \\
\hline Oil & n.s. & n.s. & n.s. & n.s. & n.s. & n.s. \\
\hline Period & n.s. & n.s. & n.s. & n.s. & $* * *$ & $* * *$ \\
\hline $\mathrm{WB} \times \mathrm{Oil}$ & n.s. & n.s. & $*$ & n.s. & n.s. & n.s. \\
\hline WB $\times$ Period & n.s. & n.s. & n.s. & n.s. & $* *$ & n.s. \\
\hline Oil $\times$ Period & n.s. & n.s. & * & n.s. & n.s. & $*$ \\
\hline Oil $\times$ Period $\times$ WB & n.s. & n.s. & n.s. & n.s. & n.s. & n.s. \\
\hline SEM & 0.989 & 1.411 & 1.365 & 1.626 & 1.887 & 1.943 \\
\hline
\end{tabular}

Legend: WB: wheat bran; SEM: standard error of means; n.s. $=\mathrm{p}>0.1 ;^{*}=\mathrm{p}<0.1{ }^{* *}=\mathrm{p}<0.05 ;{ }^{* * *}=\mathrm{p}<0.001$

soybeans, rapeseed meal, sunflower meal, WB, and soy oil as main components. A detailed description of the chemical composition of the six diets applied in the experimental period of this study was published previously (Wanzenböck et al., 2018). Aiming at a calculated crude protein concentration of $170 \mathrm{~g} / \mathrm{kg}$, the analyzed levels were slightly higher and the target $\mathrm{AME}_{\mathrm{N}}$ value of 11.4 was somewhat lower. To meet the energy requirements in the feed, it was inevitable to add some oil to the diets containing WB. Owing to the higher oil supplementations in the diets containing WB, the EE concentrations increased in parallel with the amount of WB administered. Regarding the phytate content, similar effects were observed (Wanzen- böck et al., 2018). As a cause of the higher oil levels in the diets containing elevated amounts of WB, the diets containing sunflower oil showed higher concentrations of polyunsaturated fatty acids (PUFA), saturated fatty acids (SFA), and $\sum$ n-6 PUFA (omega- 6 polyunsaturated acids) and an increased ratio of $\sum$ n- 6 PUFA to $\sum$ n-3 PUFA (the percentage of distribution between $\sum \mathrm{n}-3$ PUFA and $\sum$ n-6 PUFA). Furthermore, monounsaturated fatty acids (MUFA) and $\sum$ n-3 PUFA (omega-3 polyunsaturated acids) were observed in lower concentrations. Owing an unavoidable low sample weight applied in the analysis of $\alpha$-tocopherol, phosphorus, and calcium, slight differences in the diets resulted from analytical variabilities. 
Table 3. Concentrations of short-chain fatty acids and the percentage of distribution of acetic acid, propionic acid, and butyric acid, as well as branched-chain fatty acids, in the excrement samples collected from hens fed with different wheat bran (WB) levels and oil supplementations. Data represent LS means and standard error of means (SEM), as well as significance levels of the influence of WB and oil supplementation, including their interaction $(\mathrm{WB} \times \mathrm{Oil})$.

Tabelle 3. Konzentration der kurzkettigen Fettsäuren, sowie die prozentuelle Verteilung von Acetat, Propionat, Butyrat und den verzweigten kurzkettigen Fettsäuren in den Exkrementen von Legehennen, die mit ansteigenden Gehalten von Weizenkleie sowie verschiedenen pflanzlichen Ölen gefüttert wurden. Die Daten zeigen die LS-Mittelwerte, den Standardfehler der Mittelwerte und das Signifikanzlevel von Weizenkleie und Öl sowie deren Interaktionen.

\begin{tabular}{|c|c|c|c|c|c|c|c|c|c|c|}
\hline \multirow[b]{2}{*}{ Parameters $^{2}$} & \multicolumn{6}{|c|}{ Feed } & \multirow[b]{2}{*}{ SEM } & \multirow{2}{*}{$\begin{array}{c}\text { WB } \\
\text { p-Value }\end{array}$} & \multirow{2}{*}{$\begin{array}{c}\text { Oil } \\
\text { p-Value }\end{array}$} & \multirow{2}{*}{$\begin{array}{l}\text { WB*Oil } \\
\text { p-Value }\end{array}$} \\
\hline & CONR & CONS & LOW R & LOW S & HIGH R & HIGH S & & & & \\
\hline \multicolumn{11}{|c|}{ Concentration $(\mathrm{mmol} / \mathrm{kg})$} \\
\hline Acetic acid & 13.18 & 11.42 & 22.51 & 25.02 & 27.09 & 47.76 & 4.983 & $* * *$ & $* * *$ & $* * *$ \\
\hline Propionic acid & 0.37 & 0.47 & 1.06 & 1.55 & 1.96 & 2.74 & 0.303 & $* *$ & n.s. & n.s. \\
\hline Iso-butyric acid & 0.12 & 0.18 & 0.20 & 0.35 & 0.25 & 0.18 & 0.048 & n.s. & n.s. & n.s. \\
\hline Butyric acid & 0.30 & 0.15 & 0.63 & 0.60 & 0.89 & 1.76 & 0.174 & $* *$ & n.s. & n.s. \\
\hline Iso-valeric acid & 0.06 & 0.04 & 0.13 & 0.18 & 0.14 & 0.30 & 0.036 & n.s. & n.s. & n.s. \\
\hline Valeric acid & 0.01 & 0.01 & 0.04 & 0.03 & 0.15 & 0.14 & 0.018 & $* *$ & n.s. & n.s. \\
\hline Caproic acid & 0.02 & 0.02 & 0.04 & 0.09 & 0.12 & 0.09 & 0.015 & * & n.s. & n.s. \\
\hline BCFA & 0.18 & 0.22 & 0.32 & 0.53 & 0.39 & 0.48 & 0.068 & n.s. & n.s. & n.s. \\
\hline Total & 14.07 & 12.29 & 24.60 & 27.82 & 30.60 & 52.97 & 5.496 & n.s. & n.s. & n.s. \\
\hline \multicolumn{11}{|c|}{ Percentage of distribution (\%) } \\
\hline Acetic acid & $94.7^{\mathrm{a}}$ & $95.25^{\mathrm{a}}$ & $93.77^{\mathrm{a}}$ & $93.54^{\mathrm{a}}$ & $90.81^{\mathrm{a}}$ & $90.07^{\mathrm{b}}$ & 0.543 & $* * *$ & n.s. & n.s. \\
\hline Propionic acid & 2.95 & 3.25 & 3.92 & 4.50 & 6.02 & 5.87 & 0.363 & $* *$ & n.s. & n.s. \\
\hline Butyric acid & $2.34^{\mathrm{a}}$ & $1.50^{\mathrm{b}}$ & $2.31^{\mathrm{a}}$ & $1.96^{\mathrm{a}}$ & $3.18^{\mathrm{a}}$ & $4.06^{a}$ & 0.250 & ** & n.s. & n.s. \\
\hline BCFA & 0.18 & 0.22 & 0.32 & 0.53 & 0.39 & 0.48 & 0.068 & n.s. & n.s. & n.s. \\
\hline
\end{tabular}

BCFA: Branched chain fatty acids; CON R: control group, no wheat bran, rapeseed oil; CON S: control group, no wheat bran, sunflower oil; LOW R: 75 g/kg wheat bran, rapeseed oil; LOW S: 75 g/kg wheat bran, sunflower oil; HIGH R: $150 \mathrm{~g} / \mathrm{kg}$ wheat bran, rapeseed oil; HIGH S: $150 \mathrm{~g} / \mathrm{kg}$ wheat bran, sunflower oil; n.s. $=\mathrm{p}>0.1 ;^{*}=\mathrm{p}<0.1 ;{ }^{* *}=\mathrm{p}<0.05 ;^{* * *}=\mathrm{p}<0.001$; Identical superscripts represent no significant difference, whereas differing letters indicate a significant distinction.

\subsection{Total tract apparent digestibility of nutrients, minerals, and energy}

The effects of the adaption time on CTTAD and CTTAR were hardly pronounced. To avoid redundant information, only the CTTAD and CTTAR of the second period are considered in detail.

Poultry usually possesses a very low capacity to ferment dietary fiber in its intestine. This even might induce adverse effects on the digestion process, for example, encountering high viscosities of the digesta and a hampered interaction with pancreatic and other enzymes (Jørgensen et al., 1996; Jaroni et al., 1999). As far as WB is concerned, arabinoxylan embedded in the lignocellulosic structure could trigger some of these negative effects. Practically, dietary metabolizable energy decreases with higher levels of dietary fiber in the diet. To compensate for the lack of metabolizable energy resulting from WB administration, we successfully balanced the energy level by adding higher contents of veg- etable oil, resulting in a similar performance between the treatments (data not shown; for details, see Wanzenböck et al., 2018). Dietary fiber stimulates the secretion of bile acids, which in turn enables improved fat emulsification (Hetland et al., 2003); thus digestibility of EE was not impaired. One possible explanation for the absence of positive effects of EE digestibility could be related to the formation of less-digestible calcium-oil complexes because of higher oil supplementations (Fuhrmann et al., 2016). In general, it is assumed that because of an ameliorated gizzard development, dietary fiber supplementation stimulates $\mathrm{HCl}$ secretion in the proventriculus resulting in lower $\mathrm{pH}$ values (Svihus et al., 2004; Jiménez-Moreno et al., 2013a). Thus, calcium solubility may have been enhanced (Guinotte et al., 1995). According to our data, improved calcium solubility may have compensated for some negative effects resulting from WB supplementation. However, the digestibility of dry matter and starch, as well as the retention of ash, zinc, 
sodium, and phosphorus, was impaired on dietary supplementation with WB. It is well established that the digestibility of components such as starch, minerals, and protein of WB is hampered by the aforementioned detrimental effects on the digestion process of WB-containing feed (Jørgensen et al., 1996; Jaroni et al., 1999). We assume that although the feed was supplemented with non-starch polysaccharidecleaving enzymes, some increased viscosity and reduced enzymatic activities could not be circumvented and thus resulted in decreased digestibility and retention. Such an adverse impact on resorption is in agreement with the findings of Jiménez-Moreno et al. (2013b), who reported their experiences during a study with broiler chicks fed with fiberenriched diets supplemented with oat hulls and sugar beet pulp. While a low-fiber content increased CTTAR of all nutrients and $\mathrm{ME}$, the diet high in fiber showed a detrimental effect. Although the mechanism behind this is yet unclear, the authors suggested that a moderate fiber inclusion in the diet may be useful in maintaining the natural function of the gizzard and the integrity of the mucosa in the small intestine. Similar findings were reported by Khempaka et al. (2016), whose laying hens' diets were supplemented with $50,100,150,200$, and $250 \mathrm{~g} / \mathrm{kg}$ of dried cassava pulp, respectively. Up to $200 \mathrm{~g} / \mathrm{kg}$ ( $58 \mathrm{~g} / \mathrm{kg}$ of crude fiber), they did not observe any negative effect on the digestibility of dry matter, organic matter, and nitrogen retention, while $250 \mathrm{~g} /$ $\mathrm{kg}(73 \mathrm{~g} / \mathrm{kg}$ of crude fiber) of dried cassava pulp in the diet resulted in impaired digestibility and retention of all nutrients. Taking into account that the three diets applied in the present study had crude fiber levels of 20,28 , and $31 \mathrm{~g} / \mathrm{kg}$, respectively, the findings are in accordance with the aforementioned studies. Among these, and also compared with other feed components, the phytic acid content in WB is remarkably higher, thus causing inhibitory effects on mineral resorption, because of complexation of phytate (Kraler et al., 2014). However, as phytase was added to the feed, the negative effect on digestibility seems to be alleviated. Although high amounts of oil can evoke increased diet retention rates, because of reduced intestinal transit time (Walugembe et al., 2014), our results did not support such enhanced nutrient retention. Hence, we may postulate that oil supplementation does not affect the digestibility and retention, in contrast to WB.

\subsection{Levels of short-chain fatty acids}

SCFAs are usually produced by the fermentation of dietary fiber and also may result from resistant starch, oligosac- charides, proteins, and amino acids. BCFAs are solely formed from proteins and amino acids and usually represent precursors in the formation of longer-chain fatty acids and aldehydes in the metabolism. Generally, acetate is the most abundant SCFA produced by microorganisms in the gut, followed by propionate and butyrate (Nyangale et al., 2012). In spite of these general facts, in the present study, the inclusion of dietary fiber sources, such as WB in the diet did not influence the total amount of SCFA, although the relevance of the SCFAs detected was in accordance with the literature (Walugembe et al., 2015; Kimiaeitalab et al., 2017). WB usually contains about $15-40 \mathrm{~g} / \mathrm{kg}$ soluble and 350-484 g/kg insoluble fiber (Schedle et al., 2008; Stevenson et al., 2012). In general, insoluble fiber is not efficiently fermented in the gut of laying hens; thus the different feeding regimens resulted in comparable SCFA levels, regardless of the fiber content (Walugembe et al., 2015). However, while the percentage of distribution of SCFA was affected by the addition of WB, compositionally driven shifts of acetic acid, propionic acid, and butyric acid were hardly pronounced. As already reported in the literature, butyrate is the main source of energy for the colonocytes (Nyangale et al., 2012). This is of relevance, because the control group receiving sunflower oil (CON S) showed a lower relative butyric acid concentration compared to the WB-enriched feeding regimens. Our findings are concordant with those of previous studies such as that of Kimiaeitalab et al. (2017), who made a trial with broilers subjected to high-fiber diets supplemented with $30 \mathrm{~g} / \mathrm{kg}$ sunflower hulls, where no effect on SCFA composition was observed. We conclude that despite of some compositional shifts, WB as a not easily fermentable fiber source did not increase the total amount of SCFA in the gut.

\subsection{Prefeeding period}

According to the literature, the prefeeding period chosen differs to a very large extent, ranging from 3 days up to 3 weeks, for feeding experiments when investigating the nutrient digestibility and retention of laying hens (Mirzaie et al., 2012; Khempaka et al., 2016). In our experiment, we compared a prefeeding period of at least 3 days with an expanded period of 15 days. Interestingly, considering crude protein and dry matter, we did not observe pronounced effects resulting from the prefeeding periods, regarding neither the CTTAR nor the CTTAD. However, a longer prefeeding period decreased the CTTAR of phosphorus and the CTTAD of NDF. According to the 
Regulation for Animal Studies BGBI Nr. 114/2012 \$6, for feeding experiments, it is aimed to keep laying hens as short as possible in cages to maintain animal welfare demands. Following this target, it can be suggested that even an adaption time of 3 days seems to be sufficient to obtain meaningful results. However, for research questions regarding the dietary fiber digestibility or macroelement retentions, longer prefeeding periods need to be applied.

\section{Conclusion}

The results obtained in this study allow two major conclusions: first, it could be demonstrated that regardless of the fiber contents and the concomitant effect on digestibility of some nutrients, laying hens even tolerate higher fiber levels. Precondition is a balanced nutrient content between diets. Therefore, WB supplementation can be regarded as an interesting option for a sustainable utilization of by-products in the production of food of animal origin. Second, for digestibility trials with laying hens, an adaption time of 3 days is sufficient for producing meaningful results in regard to the CTTAD and CTTAR parameters, as far as the main nutrients such as nitrogen and dry matter are concerned. Aiming at animal welfare, such a short adaption time may be of high relevance.

\section{Acknowledgments}

We gratefully acknowledge GoodMills Group GmbH, Austria, for their support.

\section{References}

Apprich, S., Tirpanalan, Ö., Hell, J., Reisinger, M., Böhmdorfer, S., Siebenhandl-Ehn, S., Novalin, S. and W. Kneifel (2014): Wheat bran-based biorefinery 2: Valorization of products. LWT - Food Science and Technology 56, 222-231.

Baiāo, N.C., and L.J.C. Lara (2005): Oil and Fat in Broiler Nutrition. Brazilian Journal of Poultry Science 7, 129141.

Bundesgesetz über Versuche an lebenden Tieren (Tierversuchsgesetz 2012 - TVG 2012) StF: BGBl. I Nr. $114 / 2012$.
Farenzena, R., Kozloski, G.V., Gindri, M. and S. Stefanello (2017): Minimum length of the adaptation and collection period in digestibility trials with sheep fed ad libitum only forage or forage plus concentrate. Journal of Animal Physiology and Animal Nutrition 101, 1057-1066.

Fuhrmann, R. and J. Kamphues (2016): Effects of fat content and source as well as of calcium and potassium content in the diet on fat excretion and saponification, litter quality and foot pad health in broilers. European Poultry Science 80, 1-12.

GFE (1999): Empfehlungen zur Energie- und Nährstoffversorgung der Legehennen und Masthühner (Broiler). Energie- und Nährstoffbedarf landwirtschaftlicher Nutztiere, Nr. 7, DLG-Verlag, Frankfurt/Main, ISBN 3-7690-0577-5.

GfE (2005): Determination of digestibility as the basis for energy evaluation of feedstuffs for pigs. In: Proceedings of the society of nutrition physiology. DLG-Verlag, Frankfurth/Main, 207-211.

Guinotte, F., Gautron, J. and Y. Nys (1995): Calcium solubility and retention in the gastrointestinal tract in chicks (Gallus domesticus) as a function of gastric acid secretion inhibition and of calcium carbonate particle size. British Journal of Nutrition 73, 125-139.

Hamer, H.M., Jonkers, D., Venema, K., Vanhoutvin, S., Troost, F.J. and R.J. Brummer (2008): Review article: the role of butyrate on colonic function. Alimentary Pharmacology and Therapeutics 27, 104-119.

Hetland, H., Svihus, B. and Å Krogdahl (2003): Effects of oat hulls and wood shavings on digestion in broilers and layers fed diets based on whole or ground wheat. British Poultry Science 44, 275-282.

Jaroni, D., Scheideler, S., Beck, M. and C. Wyatt (1999): The effect of dietary wheat middlings and enzyme supplementation II: Apparent nutrient digestibility, digestive tract size, gut viscosity, and gut morphology in two strains of leghorn hens. Poultry Science 78, 1664-1674. Jiménez-Moreno, E., Frikha, M., de Coca-Sinova, A., Lázaro, R.P. and G.G. Mateos (2013a): Oat hulls and sugar beet pulp in diets for broilers 2. Effects on the development of the gastrointestinal tract and on the structure of the jejunal mucosa. Animal Feed Science and Technology 182, 44-52.

Jiménez-Moreno, E., Frikha, M., de Coca-Sinova, A., García, J. and G.G. Mateos (2013b): Oat hulls and sugar beet pulp in diets for broilers 1 . Effects on growth 
performance and nutrient digestibility. Animal Feed Science and Technology 182, 33-43.

Jørgensen, H., Zhao, X.Q., Bach Knudsen, K.E. and B.O. Eggum (1996): The influence of dietary fiber source and level on the development of the gastrointestinal tract, digestibility and energy metabolism in broiler chickens. British Journal of Nutrition 75, 379-395.

Khempaka, S., Hokking, L. and W. Molee (2016): Potential of dried cassava pulp as an alternative energy source for laying hens. The Journal of Applied Poultry Research 25, 359-369.

Kimiaeitalab, M.V., Camara, L., Mirzaie Goudarzi, S., Jimenez-Moreno, E. and G.G. Mateos (2017): Effects of the inclusion of sunflower hulls in the diet on growth performance and digestive tract traits of broilers and pullets fed a broiler diet from zero to $21 \mathrm{~d}$ of age. A comparative study. Poultry Science 96, 581-592.

Kraler, M., Schedle, K., Domig, K.J., Heine, D., Michlmayr, H. and W. Kneifel (2014): Effects of fermented and extruded wheat bran on total tract apparent digestibility of nutrients, minerals and energy in growing pigs. Animal Feed Science and Technology 197, 121-129.

Kraler, M., Schedle, K., Schwarz, C., Domig, K.J., Pichler, M., Oppeneder, A., Wetscherek, W., Pruckler, M., Pignitter, M., Pirker, K.F., Somoza, V., Heine, D. and W. Kneifel (2015): Fermented and extruded wheat bran in piglet diets: impact on performance, intestinal morphology, microbial metabolites in chyme and blood lipid radicals. Achieves of Animal Nutrition 69, 378-398.

Makkar, H.P.S., Siddhuraju, P. and K. Becker (2007): Phytic Acid. In: Walker, J.M. (Ed.): Methods in Molecular Biology: Plant Secondary Metabolites. Humana Press Totowa, New Jersey, 23-27.

Mirzaie, S., Zaghari, M., Aminzadeh, S., Shivazad, M. and G.G. Mateos (2012): Effects of wheat inclusion and xylanase supplementation of the diet on productive performance, nutrient retention, and endogenous intestinal enzyme activity of laying hens. Poultry Science 91, 413-425.

Naumann, C. and R. Bassler (2012): Die chemische Untersuchung von Futtermitteln. VDLUFA-Verlag, Darmstadt, Germany.
Nyangale, E.P., Mottram, D.S. and G.R. Gibson (2012): Gut microbial activity, implications for health and disease: the potential role of metabolite analysis. Journal of Proteome Research 11, 5573-5585.

Schedle, K., Plitzner, C., Ettle, T., Zhao, L., Domig, K.J. and W. Windisch (2008): Effects of insoluble dietary fiber differing in lignin on performance, gut microbiology, and digestibility in weanling piglets. Achieve of Animal Nutrition 62, 141-151.

Stevenson, L., Phillips, F., O'Sullivan, K. and J. Walton (2012): Wheat bran: Its composition and benefits to health, a European perspective. International Journal of Food Science and Nutrition 63, 1001-1013.

Svihus, B., Juvik, E., Hetland, H. and Å. Krogdahl (2004): Causes for improvement in nutritive value of broiler chicken diets with whole wheat instead of ground wheat. British Poultry Science 45, 55-60.

Walugembe, M., Hsieh, J.C., Koszewski, N.J., Lamont, S.J., Persia, M.E. and M.F. Rothschild (2015): Effects of dietary fiber on cecal short-chain fatty acid and cecal microbiota of broiler and laying-hen chicks. Poultry Science 94, 2351-2359.

Walugembe, M., Rothschild, M.F. and M.E. Persia (2014): Effects of high fiber ingredients on the performance, metabolisable energy and fiber digestibility of broiler and layer chicks. Animal Feed Science and Technology $188,46-52$.

Wanzenböck, E., Apprich, S., Tirpanalan, Ö., Zitz, U., Kracher, D., Schedle, K. and W. Kneifel (2017): Wheat bran biodegradation by edible Pleurotus fungi - A sustainable perspective for food and feed. LWT - Food Science and Technology 86, 123-131.

Wanzenböck, E., Schreiner, M., Zitz, U., Bleich, B. Figl, S., Kneifel, W. and K. Schedle (2018): A Combination of Wheat Bran and Vegetable Oils as Feedstuff in Laying Hens' Diet: Impact on Egg Quality Parameters. Agricultural Sciences 9, 676-691.

Zhao, G., Nyman, M. and J.A. Jonsson (2006): Rapid determination of short-chain fatty acids in colonic contents and faeces of humans and rats by acidified waterextraction and direct-injection gas chromatography. Biomedical Chromatography 20, 674-682. 